\title{
Robust
}

\author{
Research Business and Economics Studies
}

journal homepage: http://ejournal.iainkendari.ac.id/robust

\section{Analisis Strategi Bisnis Menggunakan SWOT Analyse Pada PT. Pertamina EP Asset 5 Balikpapan}

Lestari Daswan ${ }^{1}$, Tri Desi Lestari ${ }^{2}$, Arlita Aristianingsih Jufra ${ }^{3}$

${ }^{1,}$ Institut Agama Islam Negeri Kendari, ${ }^{2}$ Institut Agama Islam Negeri Kendari, Institut Agama Islam Negeri Kendari

e-cmail: ${ }^{1}$ lestaridaswan@iainkendari.ac.id, ${ }^{2}$ tdesilstri@gmail.com, ${ }^{3}$ arlitaajufra@iainkendari.ac.id

\begin{tabular}{l} 
ARTICLE INFO \\
\hline Keywords: \\
Straregi, Pengembangan Bisnis, SWOT, \\
QSPM
\end{tabular}

QSPM

\section{Article History:}

Received 10 January 2021

$1^{\text {st }}$ Received in revised form 12 February 2021

$2^{\text {nd }}$ Received in revised form 7 March

2021

$3^{\text {rd }}$ Received in revised form 27 April 2021

Available online 30 April 2020

http://dx.doi.org/

(c) 2021 Robust. All rights

reserved
A B S T R A C T

Artikel ini adalah hasil penelitian yang menganalisis strategi bisnis menggunakan SWOT analyse pada PT. Pertamina EP Asset 5 Balikpapan. Tujuan dari penelitian yakni untuk menganalisis dan mengendalikan faktor-faktor yang termasuk dalam lingkungan internal dan eksternal dalam menentukan beberapa alternatif strategi bisnis dan untuk menentukan strategi bisnis yang menjadi rekomendasi prioritas untuk digunakan oleh PT. Pertamina EP Cabang Balikpapan yang menggunakan QSPM berdasarkan strategi prioritas dari hasil analisis SWOT. Metode penelitian yang dilakukan dalam penelitian ini adalah metode penelitian deskriptif dengan pendekatan kualitatif. Populasi dalam penelitian ini adalah 105 karyawan dan sampel dalam penelitian sebanyak 7 orang karyawan PT. Pertamina EP Asset 5 Balikpapan yang terdiri dari 1 orang General Manager Asset 5, 1 orang Planning and Risk Management Manager, dan 5 orang karyawan Asset 5 Planning and Risk Management. Hasil penelitian ini menunjukkan bahwa strategi SO yang muncul dari hasil SWOT pada penelitian ini yakni peningkatan teknologi untuk mendukung penyediaan produk yang berkualitas tinggi, menurunkan harga jual, memperhatikan kinerja HSE pengelolaan migas, melakukan pelatihan terhadap para karyawan, dan menjunjung tinggi kepercayaan dan integritas. Adapun yang menjadi prioritas pertama berdasarkan QSPM yakni pengembangan teknologi pengeboran yang harus segera dilaksanakan sebagai strategi bisnis PT. Pertamina EP Asset 5 Balikpapan. 


\section{Pendahuluan}

Industri manufaktur memiliki peran yang sangat besar bagi perekonomian Indonesia, oleh sebab itu strategi pengembangan industri manufaktur harus tepat sasaran, strategi pengembangan mengacu pada kebijakan yang dilakukan oleh negara-negara maju dalam membangun industri. Pengembangan industri manufaktur terbagi dalam beberapa tahap yaitu: perencanaan, pembangunan, pengelolaan dan pemasaran. Sehingga itu dibutuhkan kebijakan agar dapat meningkatkan pertumbuhan ekonomi di Indoensia (http://www.academia.ew)

Salah satu faktor yang mendukung keberhasilan industri di Indonesia adalah sangat dipengaruhi oleh adanya bahan bakar minyak. Bahan bakar minyak di Indonesia sangat diperlukan, sebab tanpa adanya bahan bakar minyak maka kegiatan produksi bagi masing-masing perusahaan industri tidak akan melakukan aktivitasnya, sehingga dengan pentingnya kebutuhan bahan bakar minyak bagi setiap perusahaan Manufaktur maka kebutuhan bahan bakar minyak semakin meningkat untuk setiap tahunnya. Hal ini dapat dilihat dari tingkat konsumsi bahan bakar minyak (BBM) sepanjang tahun 2018 sebesar 75 juta kilo liter.

Bahan bakar minyak merupakan kebutuhan dasar dalam industri di seluruh dunia, tetapi bahan bakar minyak merupakan faktor sumber daya alam yang tidak dapat diperbaharui. Kebutuhan bahan bakar minyak baik dalam industri maupun transportasi semakin hari semakin meningkat karena membutuhkan bahan bakar minyak dapat menyebabkan kelangkaan bahan bakar minyak tersebut, namun kebutuhan yang semakin tinggi terhadap BBM tidak didukung dengan sumber daya alam yang mengalami penurunan.

Pentingnya fungsi dan peran bahan bakar minyak maka yang ditekankan obyek dalam penelitian ini adalah PT. Pertamina, yang berperanan dalam mendistribusikan sumber energi ke pelosok negeri. Pertamina atau nama resminya PT. Pertamina (Persero) yang merupakan sebuah perusahaan BUMN yang bertugas mengelola penambangan minyak dan gas bumi di Indonesia, dimana kegiatan pertamina dalam menyelenggarakan usaha di bidang energi dan petrokimia terbagi dalam sektor hulu dan hilir.

Kinerja usaha pada PT. Pertamina (Persero) untuk 2 tahun terakhir mengalami penurunan, hal ini dapat dilihat dari kinerja produksi minyak mentah tahun 2017 yang naik sebesar 9,40\% dan 114,03 MMBOE (Million Barrels of Oil Equivalent) jika dibandingkan dengan tahun 2016. Sedangkan tingkat produksi gas bumi tahun 2017 naik sebesar 5,80\% dari 717,70 BSCF (Billion Cubic Feet) pada tahun 2016. Selain itu produksi minyak bumi operasi sendiri tahun 2017 naik 28,20\% dan 3.042,83 GWH pada tahun 2016 (http://www.pertamina.com)

Kemudian dilihat aspek penjualan dan perolehan laba PT. Pertamina untuk 2 tahun terakhir (20162017) yang menunjukkan bahwa penjualan dan pendapatan usaha tahun 2017 naik 17,7\% dan USD 36,49 miliar pada tahun 2016. Namun laba bersih tahun 2017 turun 19,3\% dan USD 3,16 miliar pada tahun 2016 (http://www.pertamina.com) sehingga dapat disimpulkan bahwa laba usaha yang dicapai oleh PT. Pertamina (Persero) dewasa ini terlihat bahwa laba bersih tahun 2017 jika dibandingkan dengan tahun 2016 mengalami penurunan, sehingga dalam mengetahui penurunan maka akan dilakukan formulasi strategi keuangan dengan analisis SWOT analisis. Menurut Rangkuti (2015:70) mengemukakan penelitian menunjukkan bahwa kinerja perusahaan dapat ditentukan oleh kombinasi faktor internal dan eksternal, kedua faktor tersebut harus dipertimbangkan dalam analisis SWOT. SWOT adalah singkatan dari lingkungan internal strengths dan weakneses serta lingkungan eksternal yaitu opportunities dan threats.

Penelitian yang dilakukan oleh Kuswoyo (2016) yang hasil penelitian dengan analisis SWOT yang menunjukkan bahwa posisi perusahaan berada pada kuadran yang mendukung pertumbuhan yang agresif (growth oriented strategy). Sedangkan penelitian yang dilakukan oleh Setyawati dan Keso (2018) yang menunjukkan bahwa dalam penentuan strategi keuangan dengan analisis SWOT yang menunjukkan bahwa dalam analisis SWOT berada pada kuadran pertumbuhan atau shir positif sehingga dinilai mampu mengetahui kelemahan dan ancaman yang dihadapinya.

Hasil analisis SWOT akan digunakan dalam pemilihan strategi yang tepat dengan menggunakan

QSPM. Matriks QSPM merupakan alat analisis yang digunakan dalam tahap keputusan. QSPM 
menggunakan masukan dari matriks IFE dan EFE pada tahap input, serta matriks IE dan SWOT pada tahap pencocokan untuk memutuskan strategi mana yang terbaik. Strategi yang dihasilkan diharapkan dapat menjadi pertimbangan bagi pihak manajemen perusahaan dalam penetapan kebijakan strategi untuk pengembangan usaha (Baroto dan Purbohadi 2014).

Menyadari akan pentingnya analisis SWOT dan QSPM dalam penentuan strategi usaha maka penelitian ini difokuskan pada analisis SWOT dan penentuan strategi prioritas menggunakan pada PT. Pertamina EP Asset 5 Balikpapan yang merupakan salah satu perusahaan besar BUMN di Indonesia, perubahaan BUMN yang bergerak dalam perminyakan bisnis yang dijalankan adalah pengolahan minyak yang dimulai dari hulu hingga hilir dan pemasaran. Sehingga dapat dikatakan bahwa perusahaan PT. Pertamina EP Asset 5 Balikpapan yang merupakan salah satu perusahaan yang berpengaruh terhadap laju perekonomian Negara Indonesia. Bidang pengolahan minyak khususnya pada perusahaan PT. Pertamina EP Asset 5 Balikpapan yang memiliki 7 unit kilang dengan kapasitas total sebesar 1.041,20 ribu barrel.

Usaha yang dijalankan oleh PT. Pertamina EP Asset 5 Balikpapan selama ini maka perusahaan tersebut di atas memiliki tantangan dan kendala, dimana dari data yang diperoleh pada PT. Pertamina EP Asset 5 Balikpapan selama ini khususnya dalam tahun 2017 yang menunjukkan bahwa realisasi produksi minyak tahun 2017 mencapai 77.154 barrel atau 91\% dari target RKP tahun 2017 sebanyak 85.000 BPD (Barrel Per Day). Produksi minyak terbesar di dapat dari 2 sebesar 17,4 BOPD (Barrel Oil Per Day) atau 23\% dari total produksi PT Pertamina EP dan produksi terendah diperoleh dari mitra sebesar 6,4\% BOPD (Barrel Oil Per Day) atau 8\% dari total produksi pertamina EP Asset 5 (Sumber : laporan tahunan PT. Pertamina EP Asset 5 Balikpapan, 2017). Berdasarkan laporan tahunan dari PT. Pertamina EP Asset 5 Balikpapan menunjukkan bahwa kinerja keuangan dalam tahun 2017 mengalami penurunan.

\section{Kajian Literatur}

Analisis SWOT merupakan teknik historis yang terkenal dimana manajer menciptakan gambaran umum secara tepat mengenai situasi strategi perusahaan. Analisis ini didasarkan pada asumsi bahwa strategi yang efektif diturunkan dari "kesesuaian" yang baik antara sumber daya internal perusahaan (kekuatan dan kelemahan) dengan situasi eksternalnya (peluang dan ancaman), kesesuaian yang baik antara memaksimalkan kekuatan dan peluang perusahaan serta meminimalkan kelemahan ancaman. Jika diterapkan secara akurat, asumsi sederhana ini memiliki implikasi yang bagus dan mendalam bagi desain serta strategi yang berhasil.

Menurut Rangkuti (2016:198) bahwa analisis SWOT adalah identifikasi berbagai faktor secara sistematis untuk merumuskan strategi perusahaan. Analisis ini didasarkan pada logika yang dapat memaksimalkan kekuatan (strengths) dan peluang (oppurtunities), namun secara bersamaan dapat meminimalkan kelemahan (weaknesses) dan ancaman (threats).

Fahmi (2013:344) mengemukakan bahwa SWOT adalah singkatan dari strengths (kekuatan), weaknesses (kelemahan), opportunities (peluang), dan threats (ancaman), dimana SWOT ini dijadikan sebagai suatu odel dalam manganalisis suatu organisasi yang berorientasi profit dan non profit dengan tujuan utama untuk mengetahu keadaan organisasi tersebut secara lebih komprehensif.

Sedarmayanti (2014:110) mengatakan bahwa analisis SWOT merupakan kerangka pilihan bagi banyak manajer selama periode waktu yang panjang, karena kesederhanaannya dan kemampuannya untuk menggambarkan esensi dari formulasi strategi yang baik, menyesuaikan peluang dan ancaman suatu perusahaan dengan kekuatan dan kelemahannya.

Diluar strategi-strategi pemeringkatan untuk mendapatkan daftar prioritas, hanya ada satu teknik analitis dalam literatur yang dirancang untuk menentukan daya tarik relatif dari berbagai tindakan alternatif. Teknik tersebut adalah Matriks Perencanaan Strategis Kuantitatif (Quantitative Strategic Planning MatrixQSPM), yang menyusun Tahap 3 dari kerangka analitis perumusan strategi. Teknik ini secara objektif menunjukkan strategi mana yang terbaik. QSPM menggunakan analisis input dari Tahap 1 dan hasil 
pencocokan dari analisis Tahap 2 untuk secara objektif menentukan strategi yang hendak dijalankan di antara strategi-strategi alternatif. Itu artinya, Matriks EFE, Matriks IFE, dan Matriks Profil Kompetitif yang menyusun Tahap 1, ditambah dengan Matriks SWOT, Matriks SPACE, Matriks IE, dan Matriks Grand Strategy yang menyusun Tahap 2, menyediakan informasi yang dibutuhkan untuk menyusun QSPM (Tahap 3). QSPM adalah alat yang memungkinkan para penyusun strategi mengevaluasi berbagai strategi alternatif secara objektif, berdasarkan faktor-faktor keberhasilan penting eksternal dan internal yang diidentifikasi sebelumnya.

\section{Metode Penelitian}

\subsection{Pendekatan Penelitian}

Pendekatan penelitian yang digunakan pada penelitian ini adalah pendekatan kualitatif. Pendekatan kualitatif artinya data yang dikumpulkan sesuai fakta dilapangan, memanfaatkan teori yang ada sebagai bahan penjelasan, bukan berupa angka-angka, melainkan data tersebut berasal dari naskah wawancara, catatan lapangan, dokumen pribadi, catatan memo, dan dokumen resmi lainnya dan dideskripsikan dalam bentuk narasi. Memusatkan pada pemecahan masalah yang tepat mengenai kekuatan, kelemahan, peluang dan ancaman mengimplementasikan teknologi finansial pada PT. Pertamina EP Balikpapan.

3.2 Jenis Data Penelitian

Jenis data yang digunakan dalam peneltian ini adalah:

1. Data Kualitatif, yaitu nilai dari perubahan-perubahan yang tidak dapat dinyatakan dalam angkaangka (statistik). Jadi data kualitatif adalah data yang berupa kata dan atau kalimat, gambar, skema yang belum diangkakan. Data kualitatif yang peneliti peroleh dari perusahaan tidak berbentuk angka-angka

2. Data Kuantitatif, yaitu data numerik untuk dapat menghasilkan penafsiran yang kokoh atau dengan kata lain data ini berupa angka yang diperoleh dari laporan keuangan yang berhubungan dengan penulisan ini, seperti data penjualan serta data lainnya yang menunjang penelitian ini.

\subsection{Sumber Data Penelitian}

Sumber data yang digunakan dalam penelitian ini bersumber dari :

1. Data primer adalah data yang diperoleh langsung oleh peneliti dari objek penelitian melalui observasi atau pengamatan langsung dan wawancara secara langsung dengan staff karyawan sesuai dengan data yang diperlukan peneliti dalam penelitian.

2. Data Skunder adalah semua data yang diperoleh secara tidak langsung dari objek penelitian, yaitu data tersebut diperoleh peneliti dari dokumen-dokumen perusahaan dan buku-buku literatur yang memberikan informasi yang dibutuhkan peneliti.

3.4 Teknik Penentuan Informan Atau Responden

Untuk menentukan informan dalam penelitian ini, peneliti memilih Teknik purposive sampling dan Snowball Sampling. Teknik purposive sampling adalah teknik pengambilan sampel sumber data dengan pertimbangan tertentu. Pertimbangan tertentu ini, misalnya orang tersebut yang dianggap paling tahu tentang apa yang kita harapkan, atau mungkin dia sebagai penguasa sehingga akan memudahkan peneliti menjelajahi objek/situasi sosial yang diteliti. Dalam teknik purpose sampling peneliti memilih subyek penelitian dengan tujuan untuk menentukan informan kunci (key informan) yang sesuai dengan fokus penelitian yangdilakukan secara sengaja tanpa dibuat-buat untuk mendapatkan kekuatan akurasinya. Sedangkan untuk menambah kredibilitas data, peneliti juga menggunakan teknik snowball sampling yang mana bertujuan untuk mengembangkan informasi dari informan yang telah ditentukan (Sugiyono, 2014). 
Pada penelitian ini, yang menjadi intrumen utamanya adalah peneliti sendiri, namun selanjutnya setelah fokus penelitian menjadi jelas, maka kemungkinan akan dikembangkan instrument penelitian sederhana, yang diharapkan dapat melengkapi data dan membandingkan dengan data yang telah ditemukan.

3.6 Teknik Pengumpulan Data

Dalam penelitian ini, teknik pengumpulan data yang dapat digunakan adalah riset lapangan yaitu riset yang dilakukan dengan mendatangi secara langsung lapangan yang menjadi objek penelitian yaitu PT.Pertamina EP Asset 5 Balikpapan. Dalam riset ini, peneliti menggunakan beberapa metode pengumpulan data yaitu: wawancara, dokumentasi, dan observasi.

\subsection{Teknik Analisis Data}

Untuk menjawab permasalahan yang dihadapi oleh perusahaan, maka digunakan teknik analisis data sebagai pemecahan atas masalah tersebut sebagai berikut: analisis SWOT, matriks SWOT, matriks evaluasi faktor internal (Matriks IFE), matriks evaluasi faktor ekternal (Matriks EFE), dan matriks QSPM.

\subsection{Kredibilitas Data}

Untuk memudahkan dalam mengumpulkan data-data yang diperlukan, serta kepercayaan terhadap data hasil kebenaran penelitian ini, maka peneliti melakukan perpanjangan pengamatan atau kunjungan setiap hari pada PT. Pertamina Asset 5 Balikpapan, serta melakukan interview atau wawancara dengan bagian pemasaran untuk mendapatkan data-data yang dibutuhkan, kemudian peneliti melakukan triangulasi dengan mewawancarai bagian lainnya yang diperoleh dari studi dokumentasi, penelitian-penelitian sebelumnya dan teori-teori yang mendukung, agar dapat diperoleh data yang valid.

\section{Hasil}

\subsection{Analisis Lingkungan Internal}

PT. Pertamina EP Asset 5 Balikpapan merupakan bagian dari PT. Pertamina (Persero) yang berperan dalam penegelolaan bahan mentah menjadi bahan bakar minyak dimana PT. Pertamina EP Asset 5 Balikpapan telah mampu menyediakan produk yang berkualitas dengan mengusai 40\% produksi minyak nasional tahun 2019 dan dipersiapkan menjadi 60\% pada tahun 2021. Hal tersebut tidak terlepas dari sumber daya manusia kualitas handal yang telah melalui seleksi yang ketat dengan pelatihan serta pendampingan secara baik dan professional baik sebelum maupun saat melaksanakan pekerjaan. Disamping itu para sumberdaya manusia pada PT. Pertamina EP Asset 5 Balikpapan ditekankan untuk menjaga keceperyaaan serta integritas perusahaan. Hasil analisis inilah yang digunakan untuk melakukan analisis SWOT.

Solihin (2017:164) mengemukakan bahwa salah satu alat analisis situasional yang paling bertahan lama dan banyak digunakan oleh perusahaan dalam melakukan formulasi strategi adalah analisis SWOT (strengths, weaknesses, opportunities, dan threats). Hasil dari analisis SWOT adalah identifikasi distinctive competencies perusahaan yang berasal dari sumber daya dan kemampuan internal yang dimiliki perusahaan serta sejumlah peluang yang selama ini belum dimanfaatkan perusahaan, misalnya akibat adanya kekurangan dalam kemampuan internal perusahaan.

Fahmi (2013:353) mengemukakan bahwa faktor internal ini mempengaruhi terbentuknya strengths and weaknesses ( $S$ and $W$ ). Dimana faktor ini menyangkut dengan kondisi yang terjadi dalam 
perusahaan, yang mana ini turut mempengaruhi terbentuknya pembuatan keputusan (decision making) perusahaan. Faktor internal ini meliputi semua macam manajemen fungsional: pemasaran, keuangan, operasi, sumberdaya manusia, penelitian dan pengembangan, system informasi manajemen, dan budaya perusahaan (corporate culture).

Lingkungan internal merupakan suatu kondisi yang ada didalam organisasi yang tercipta karena proses kerja sama atau karena proses konflik yang ada didalam organisasi. Organisasi disamping terdapat proses kerja sama didalamnya juga ada proses konflik. Proses konflik dapat bersifat disfungsional atau bersifat fungsional. Lingkungan internal akan ada disetiap fungsi dan bagian. Oleh karena itu lingkungan internal harus diperhatikan. Lingkungan internal bersifat dapat dikendalikan dibandingkan dengan lingkungan eksternal. Jika lingkungan internal sudah tidak dapat dikendalikan maka perusahaan telah berada diujung kematian (kebangkrutan).

4.2 Analisis Lingkungan Eksternal

Lingkungan eksternal mengarah pada faktor peluang dan ancaman. Peluang dapat mengarahkan kegiatan organisasi sedangkan ancaman, menghambat pergerakan organisasi. Faktor eksternal yang dibahas dalam penelitian ini adalah lingkungan mikro, lingkungan industri dan lingkungan makro.

Ada beberapa faktor yang menjadi peluang bagi PT. Pertamina EP Asset 5 Balikpapan diantaranya pasar bisnis yang masih tinggi dimana penggunaan bahan bakar minyak masyarakat saat ini masih dikuasai dan berasal dari PT. Pertamina dengan harga jual yang murah dimana pemerintah telah memberlakukan satu harga untuk BBM yang berlaku hingga ke pelosok negeri.

Negara Indonesia memiliki sumber daya migas yang masih cukup tinggi sehingga diharapkan PT. Pertamina EP Asset 5 Balikpapan dapat mengelolah dengan baik sumber daya tersebut untuk keuntungan perusahaan secara khusus dan bagi negara secara umum karena PT. Pertamina berperan sebagai pemimpin dalam pasar Bahan Bakar Minyak (BBM) di Indonesia. Selain peluang, ancaman juga merupakan faktor eksternal lingkungan PT. Pertamina EP Asset 5 Balikpapan yang harus diperhatikan dalam menjalankan proses bisnis.

Pengaruh Intervensi Pemerintah pada PT. Pertamina saat ini masih sangat kuat sehingga perusahaan ini memiliki keterbatasan dalam hal ruang gerak untuk membuat kebijakan demi peningkatan perusahaan. Disamping itu tren harga migas dunia yang cenderung turun semakin membuat kondisi perusahaan semakin menjadi kesulitan dalam pengelolaan BBM yang seharusnya murah tetapi kualitas tetap terjaga. Dalam hal ini yakni kadar octannya.

Kondisi ekonomi Indonesia saat ini yang tidak terlalu baik, peningkatan inflasi yang tidak tinggi, mengidentifikasikan permintaan dan daya beli masyarakat yang kurang baik, serta nilai tukar dollar yang yang menguat juga menjadi ancaman bagi keberlangsungan perusahaan ini karena kondisi ekonomi negara akan memberi pengaruh terhadap keberlangsungan suatu perusahaan. Disamping itu adanya Peraturan Bank Indonesia No.17 tahun 2015 yang mana untuk bisnis migas barang dan jasa masih di datangkan dari luar negeri dan menggunakan mata uang pakai dollar atau vallas menjadi beban bagi PT. Pertamina.

Menurut Fahmi (2013:353) faktor eskternal mempengaruhi terbentuknya opportunities and threats $(O$ and $T$ ). Dimana faktor ini menyangkut dengan kondisi-kondisi yang terjadi di luar perusahaan. Faktor ini mencakup lingkungan industri (industry environment) dan lingkungan bisnis makro (macro environment), ekonomi, politik, hukum, teknologi, kependudukan, dan sosial budaya. 
Dalam melakukan analisa eksternal, perusahaan menggali dan mengidentifikasi semua peluang (opportunity) yang berkembang dan menjadi trend pada saat itu serta ancaman (threath) dari para pesaing dan calon pesaing. Kebanyakan perusahaan menghadapi lingkungan eksternal yang berkembang secara tepat, kompleks dan global, yang membuatnya semakin sulit diinterpretasikan. Untuk menghadapi data lingkungan yang sering kali tidak lengkap, perusahaan dapat menempuh cara yang disebut analisis lingkungan eksternal (external environmental analysis).

4.3 Analisis SWOT

Lingkungan perusahaan mencakup semua faktor baik yang berada di dalam maupun di luar perusahaan yang dapat mempengaruhi pencapaian tujuan yang diinginkan. Secara garis besar analisis lingkungan disini akan mencakup analisis mengenai lingkungan eksternal dan lingkungan internal. Lingkungan eksternal akan mencakup lingkungan umum dan lingkungan industri, sedangkan analisis internal akan mencakup analisis mengenai aktivitas perusahaan atau bisa juga analisis mengenai sumber daya, kapabilitas serta kompetensi inti yang dimiliki. Hasil dari analisis lingkungan ini setidaknya akan memberikan gambaran tentang keadaan perusahaan yang biasanya disederhanakan dengan metode SWOT (Strengths, Weaknesses, Opportunities, Threats) yang dimilikinya. Analisis eksternal akan memberikan gambaran tentang peluang dan ancaman (OT) sedangkan analisis lingkungan internal akan memberikan tentang keunggulan dan kelemahan (SW) dari perusahaan.

Hasil analisis menggunakan matriks SWOT merupakan strategi yang mengkombinasikan antara peluang dan ancaman dengan kekuatan dan kelemahan. Dalam matriks SWOT, terdapat empat strategi kombinasi yaitu :

1. Strategi SO (strenght- opportunity) pada kuadran I, rangking I.

2. Strategi ST (strenght-threats) pada kuadran II, rangking II

3. Strategi WO (weakness - opportunity) pada kuadran III, rangking IV

4. Strategi WT (weakness-threats) pada kuadran IV, rangking III

Berdasarkan penentuan luas daerah, kuadran I yang paling luas dengan letak titik potong terletak pada kuadran I, sehingga strategi yang paling utama yang harus dibenahi dari pengembangan bisnis perumahan PT. Pertamina EP Asset 5 Balikpapan adalah strategi SO. Sedangkan strategi alternatif dari pengembangan bisnis perumahan PT. Pertamina EP Asset 5 Balikpapan adalah strategi ST, WO dan WT.

Rangkuti (2016:198) mengemukakan bahwa analisis SWOT adalah identifikasi berbagai faktor secara sistematis untuk merumuskan strategi perusahaan. Analisis ini didasarkan pada logika yang dapat memaksimalkan kekuatan (strengths) dan peluang (oppurtunities), namun secara bersamaan dapat meminimalkan kelemahan (weaknesses) dan ancaman (threats). Lebih lanjut Sedarmayanti (2014:110) mengatakan bahwa analisis SWOT merupakan kerangka pilihan bagi banyak manajer selama periode waktu yang panjang, karena kesederhanaannya dan kemampuannya untuk menggambarkan esensi dari formulasi strategi yang baik, menyesuaikan peluang dan ancaman suatu perusahaan dengan kekuatan dan kelemahannya.

Hasil penelitian mendukung hasil penelitian dari Setyariningsih (2018) yang menemukan bahwa strategi SO merupakan strategi yang menggunakan kekuatan untuk meman-faatkan peluang sebesarbesarnya. Penelitian selanjutnya yang didukung dari penelitian ini yakni penelitian dari Anpi Setyawan, Evanila Silvia dan Hidayat Koto, (2018) yang bdalam penelitiannya juga menemukan bahwa strategi yang tepat adalah strategi SO (Strenght-Opportunities) untuk proses pengembangan bisnis. 
Penelitian ini menghasilkan formulasi alternatif strategi melalui matriks TOWS. Input matriks TOWS yang diperoleh dari analisis lingkungan internal dan eksternal perusahaan serta dari hasil Survei SWOT.

Strategy SO (Streght-Opportunity) terdiri dari menyediakan produk yang berkualitas tinggi untuk mempertahankan market share, menurunkan harga jual seiring dengan peningkatan kapasitas produksi, memperhatikan kinerja HSE dalam pengelolaan blok migas, melakukan pelatihan terhadap para pekerja agar lebih meningkatkan kinerja dalam pengelolaan sumber daya migas dan menjunjung tinggi kepercayaan dan integritas sebagai perusahaan yang memimpin pasar BBM di Indonesia.

Strategy WO(weakness-Opportunity) terdiri dari meningkatkan jumlah armada kapal tangker dan melakukan pengaturan distribusi pada saat harga bahan baku naik. Selanjutnya adalah Strategy ST (StreghtThreat).

Strategy ST (Streght-Threat) terdiri dari meningkatkan teknologi untuk mempercepat produksi minyak, memaksimalkan pengelolaan blok migas, mempersiapkan sumber daya manusia yang handal dalam pengelolaan teknologi pengeboran.

Strategy WT (weakness-threat) terdiri dari pengajuan subsidi kepada PT. Pertamina Persero untuk proses pengelolaan bahan mentah menjadi bahan bakar minyak (BBM), pengajuan subsidi kepada hulu migas untuk pendistribusian BBM, pengajuan peningkatan kapasitas pengeboran dengan mendirikan kilang minyak baru.

\section{Kesimpulan}

Berdasarkan hasil pembahasan yang telah diuraikan oleh peneliti, maka kesimpulan dari penelitian ini adalah sebagai berikut:

1) Strategi SO yang muncul dari hasil SWOT pada penelitian ini yakni Peningkatan teknologi untuk mendukung penyediaan produk yang berkualitas tinggi untuk mempertahankan market share, Menurunkan harga jual seiring dengan peningkatan kapasitas produksi, Memperhatikan kinerja HSE dalam pengelolaan blok migas, Melakukan pelatihan terhadap para pekerja agar lebih meningkatkan kinerja dalam pengelolaan sumber daya migas, Menjunjung tinggi kepercayaan dan integritas sebagai perusahaan yang memimpin pasar BBM di Indonesia.

2) Hasil analisis SWOT ditemukan bahwa strategi prioritas untuk pengembangan bisnis PT. Pertamina EP Asset 5 Balikpapan yakni Strategi SO (Strenght Opportunities). Adapun berdasarkan analisis QSPM maka strategi prioritas yang pertama kali harus dilakukakn oleh PT. Pertamina EP Asset 5 Balikpapan yakni pengembangan teknologi. 


\section{References}

Fahmi, Irham. 2013. Manajemen Strategis, Teori dan Aplikasi. Cetakan Kesatu. Penerbit : Alfabeta, Bandung Http://www.academia.ew

Http://www.pertamina.com

Rangkuti, Freddy. 2015. Analisis SWOT Teknik Membedah Kasus Bisnis, Cetakan Keduapuluh, Penerbit : Gramedia Pustaka Utama. Jakarta

-------.- 2016. SWOT Balanced Scorecard, Teknik Menyusun Strategi Korporat yang Efektif Plus Cara Mengelola Kinerja dan Risiko. Penerbit : PT. Gramedia Pustaka Utama, Jakarta

Sedarmayanti. 2014. Manajemen Strategi. Cetakan Kesatu. Penerbit: Refika Aditama, Bandung

Setyariningsih, E. 2018. Analisa Strategi Pengembangan UKM Sosis Sumijaya Ditinjau dari Aspek Pemasaran dan Aspek Keuangan. PRIVE: Jurnal Riset Akuntansi dan Keuangan, 1(2), 165-175.

Setyawan, Anpi dkk (2018) Analisis Finansial dan Strategi Pengembangan Usaha Industri Kue Baytat “ADN" di Kota Bengkulu. https://ejournal.unib.ac.id/index.php/agroindustri pISSN: 2088- 5369 eISSN: 26139952 DOI :10.31186/jagroindustri.8.1.71-79

Solihin, Ismail. 2017. Pengantar Manajemen. Penerbit : Erlangga, Jakarta

Sugiyono. 2010. Metode Penelitian Bisnis: Pendekatan Kuantitatif, Kualitatif dan R\&D. Bandung: Alfabeta. Sugiyono. 2014. Metode Penelitian Kuantitatif Kualitatif dan R\&D. Bandung: Alfabeta. 